\title{
IMPACT OF GREEN ECONOMY IN SUSTAINABLE DEVELOPMENT
}

\author{
Alvina Gucaj $^{1 *}$, Flora Merko², Alba Ramallari² \\ 1*Office manager, Protik Innovation Center, Tirana, Albania; \\ ${ }^{2}$ Aleksander Moisiu University, Department of Economics, Durres, Albania; \\ *Corresponding Author Alvina Gucaj, e-mail: cokualvi@gmail.com; floramerko@yahoo.it;
}

Received June 2021; Accepted July 2021; Published August 2021;

DOI: https://doi.org/10.31407/ijees11.412

\begin{abstract}
The economy is closely related to nature and the environment is absorbed to productive factors. In economic growth, the environment is considered an exogenous economic factor, while in development economics, the environment is considered an economic resource and an integral part of economic development. It "produces" wellfare for the population and thanks to related activities, can also produce economic benefits and wealth. Theories of economic growth in the past were based on the fact that to secure the needs of future generations it was necessary to provide them with a heterogeneous part of natural/artificial capital not less than the current one. Development theories now consider the loss of natural capital as irreplaceable by man-made capital. Developed countries`enterprises are oriented towards a green economy, developing countries consider, natural resources, a source for economic growth. Based on these conditions, it is important to analyze the environmental factor in Albania to understand whether the environment it is considered an endogenous factor for the economic development of the country or whether it is a primary source for economic growth. To carry out this work, the methodology used will be based on empirical analysis, to explore the influence that natural resources have had on the economic growth of the country and the evolution of the economy over the last 30 years. The expected results of this paper are: natural resources are considered a primary factor for economic growth while in contrast pollution, catastrophic natural events such as floods, frosts, or drought are increasingly damaging the country's economy.
\end{abstract}

Keywords: Green Economy, Sustainable Development, Natural Resources, Empirical Analyze. 